\title{
The Effect of Insulin on the Alpha-Cell Response to Hyperglycemia in Long-Standing Alloxan Diabetes
}

\author{
Jan T. Braaten, Gerald R. Faloona, and Roger H. Unger \\ From the Veterans Administration Hospital, Dallas, Texas 75216, and the \\ Department of Internal Medicine, The University of Texas Southwestern \\ Medical School, Dallas, Texas 75235
}

A BSTRACT In acute experimental diabetes in animals, alpha-cell unresponsiveness to hyperglycemia can be promptly corrected by insulin, but in human diabetes, even massive doses of insulin have little effect. To determine if this inability of insulin to correct the alphacell abnormality in man is merely the consequence of the long duration of the diabetic state (rather than of a difference in mechanism), the effect of insulin was studied in alloxan diabetes of long duration. Alloxan-diabetic dogs were maintained for 7-18 mo and treated daily with insulin. When glucose was infused without insulin, glucagon did not decline but rose paradoxically. However, when insulin was infused at a rate of $9 \mathrm{mU} /$ $\mathrm{kg} / \mathrm{min}$ together with glucose, a prompt decline in glucagon from a base-line average of $171 \mathrm{pg} / \mathrm{ml}$ SEM \pm 34 to a nadir of $41 \mathrm{pg} / \mathrm{ml} \mathrm{SEM} \pm 9$ was observed. This decline indicated that alpha-cell responsiveness to hyperglycemia is completely restored by large quantities of insulin. To determine if small amounts of insulin would similarly restore alpha-cell responsiveness in longstanding experimental diabetes, $1.4 \mathrm{mU} / \mathrm{kg} / \mathrm{min}$ was infused. By the time the mean insulin level had risen 43 $\mu \mathrm{U} / \mathrm{ml}$, glucagon had declined significantly and ultimately fell to a nadir of $44 \mathrm{pg} / \mathrm{ml}$. It is concluded from these studies that alpha-cell responsiveness to hyperglycemia can be fully restored in long-standing alloxandiabetic dogs as readily as in acutely diabetic dogs. Its ineffectiveness in restoring alpha-cell responsiveness to hyperglycemia in human diabetes may not, therefore, be related to duration of the diabetic state, and may reflect a primary alpha-cell defect.

This study was presented at the American Diabetes Association Meeting, 23 June 1973, Chicago, Ill.

Dr. Braaten was a Resident Clinical Associate at the Veterans Administration Hospital and is now at the University of Miami School of Medicine, Miami, Fla.

Received for publication 27 September 1973 and in revised form 6 December 1973.

\section{INTRODUCTION}

In normal human subjects (1) and dogs $(2,3)$, glucagon secretion is intimately related to blood glucose concentration and declines promptly when the glucose level rises. In both inherited and experimental diabetes this relationship is disturbed; glucagon secretion is at all times inappropriately high relative to the blood glucose level and is not suppressed by hyperglycemia (4-6). The two forms of diabetes differ strikingly with respect to the ability of insulin to restore alpha-cell function to normal. In experimental diabetes, the abnormality is promptly corrected by the administration of insulin in physiologic quantities, suggesting that it is the consequence of insulin lack (6), whereas in human diabetes alpha-cell unresponsiveness to hyperglycemia is only minimally improved by insulin, even in pharmacologic quantities (7). Moreover, the alpha-cell defect in human diabetes appears to be unrelated either to the type or the severity of the diabetes, to the degree of control, or to the level of plasma insulin and is observed in relatively mild diabetes with essentially normal plasma levels of immunoreactive insulin, as well as in severe insulinrequiring diabetics $(4,5)$.

On the basis of the inability of insulin to normalize the unresponsiveness of the alpha cell to hyperglycemia in human genetic diabetes, and because alpha and beta cells develop from a common anlage, it has been suggested that the alpha-cell defect in genetic diabetes is not secondary to insulin lack but might represent a primary alpha-cell defect inherited with the beta-cell defect (8).

As pointed out, a major point in favor of this suggestion is the striking difference between alloxan-diabetic dogs and human diabetics with respect to the ability of insulin to correct the alpha-cell unresponsiveness to hyperglycemia. However, since the human diabetics studied had been diabetic for at least 6 mo and as long 


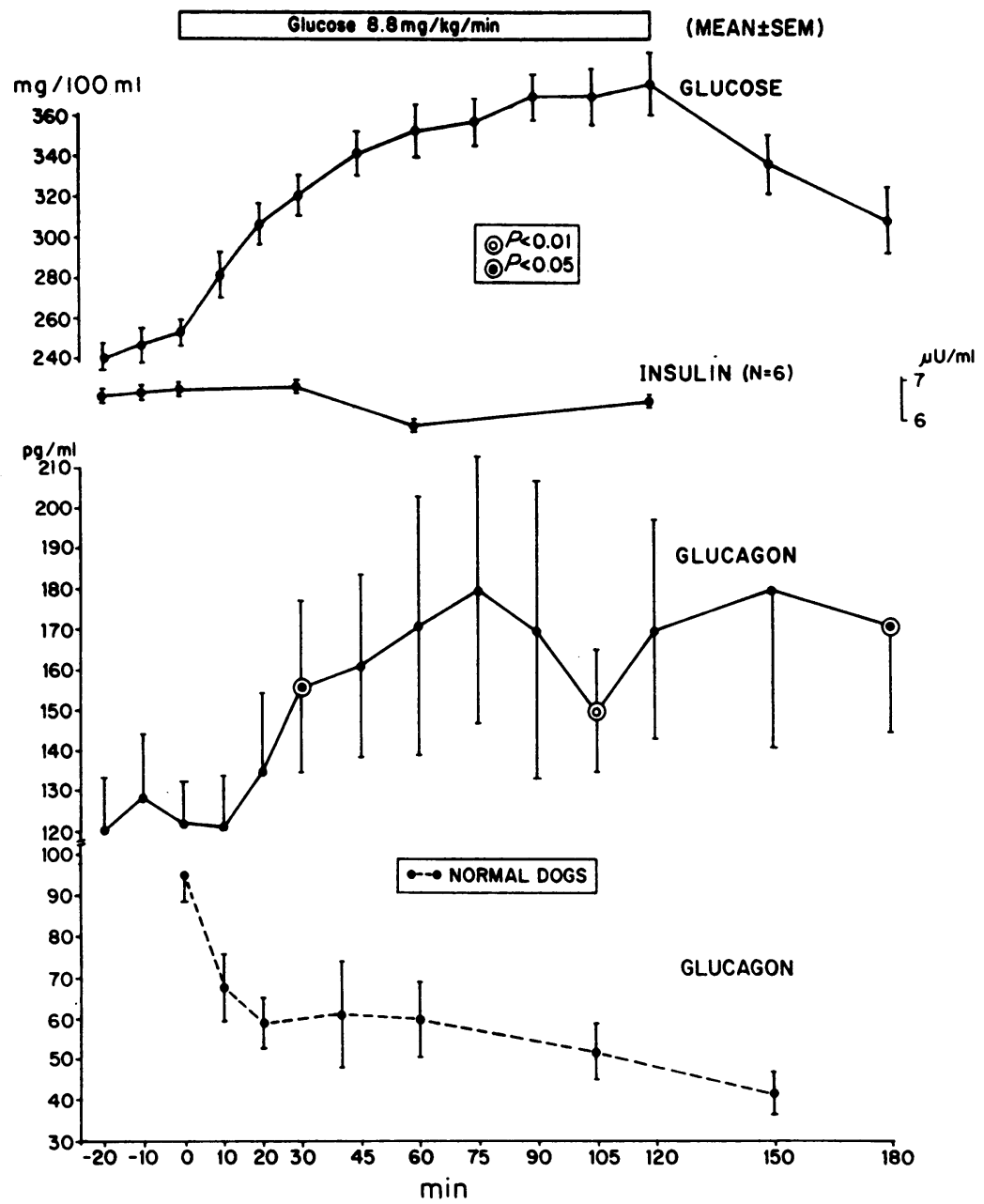

FJGURE 1 The effect of intravenous glucose infusion on mean plasma glucagon in six dogs with alloxan diabetes of 7-12 mo duration. The broken line indicates the mean glucagon level of three nondiabetic control dogs during intravenous glucose infusion.

as $15 \mathrm{yr}(7)$, whereas the alloxan-diabetic dogs were diabetic for $3 \mathrm{wk}$ or less (6), the difference in the effectiveness of exogenous insulin could well have been the consequence of difference in duration rather than in the mechanism of the alpha-cell dysfunction.

The present study was designed to determine if long duration of acquired diabetes abolishes or impairs the ability of insulin to correct the unresponsiveness of the diabetic alpha cell to hyperglycemia. This was done by studying the effect of insulin on the alpha-cell response to hyperglycemia in dogs with alloxan diabetes of long duration.

\section{METHODS}

Alloxan-diabetic dogs. Diabetes was induced in dogs by means of an intravenous injection of $75 \mathrm{mg} / \mathrm{kg}$ of alloxan. All dogs subsequently required daily injections of insulin in a dose of $8-15 \mathrm{U} / \mathrm{dog}$ throughout the ensuing 7-18 mo before their use in these experiments. Without insulin treatment the fasting plasma glucose levels of these animals ranged from 250 to $500 \mathrm{mg} / 100 \mathrm{ml}$. Insulin was discontinued $24 \mathrm{~h}$ before an experiment.

During an experiment glucagon-free insulin, ${ }^{1}$ in normal saline containing $0.35 \%$ human albumin, was infused via an indwelling catheter in a lateral saphenous vein. Blood samples were collected from an indwelling Butterfly needle in the cephalic vein of the foreleg. In nondiabetic dogs, indwelling catheters were introduced via the right jugular vein at least 2 days before an experiment. The insulin infusions were administered as described above.

Blood samples were collected in chilled tubes containing $1.2 \mathrm{mg} \mathrm{Na} 2$ EDTA and $500 \mathrm{U}$ Trasylol $/ \mathrm{ml}$ of blood collected (Trasylol, FBA Pharmaceuticals, New York).

Analytical methods. Plasma glucose was determined by the glucose oxidase method using the glucose analyzer (Beckman Instruments, Inc., Fullerton, Calif.). Insulin

${ }^{1}$ Kindly provided by Dr. John Galloway, Eli Lilly and Company, Indianapolis, Ind. 
was measured by the radioimmunoassay of Yalow and Berson (9) as modified by Herbert, Law, Gottlieb, and Bleicher (10). Glucagon was measured as described previously (11). $30 \mathrm{~K}$ antiserum, which is highly specific for pancreatic glucagon, was used for all of the glucagon assays.

\section{RESULTS}

Hyperglycemia responsiveness of the alpha cell in long-standing alloxan diabetes. To determine the hyperglycemia responsiveness of the alpha cell in the absence of additional insulin in long-standing acquired diabetes, glucose was infused at a rate of $8.8 \mathrm{mg} / \mathrm{kg} /$ min in six dogs with alloxan diabetes of 7-12 mo duration. The mean glucagon, insulin, and glucose levels are shown in Fig. 1. In contrast to the $55 \mathrm{pg} / \mathrm{ml}$ decline observed in three normal dogs (Fig. 1), in the alloxandiabetic dogs, plasma glucagon remained at or above the fasting level of $122 \mathrm{pg} / \mathrm{ml}$ throughout the $3 \mathrm{~h}$ experiment, and rose paradoxically to a peak of $180 \mathrm{pg} / \mathrm{ml}$ at 75 min despite a mean glucose level of $358 \mathrm{mg} / 100 \mathrm{ml}$ at that time. Plasma insulin averaged approximately $6 \mu \mathrm{U} /$ $\mathrm{ml}$ throughout the experiment. The increase in glucagon was statistically significant at 30,105 , and 180

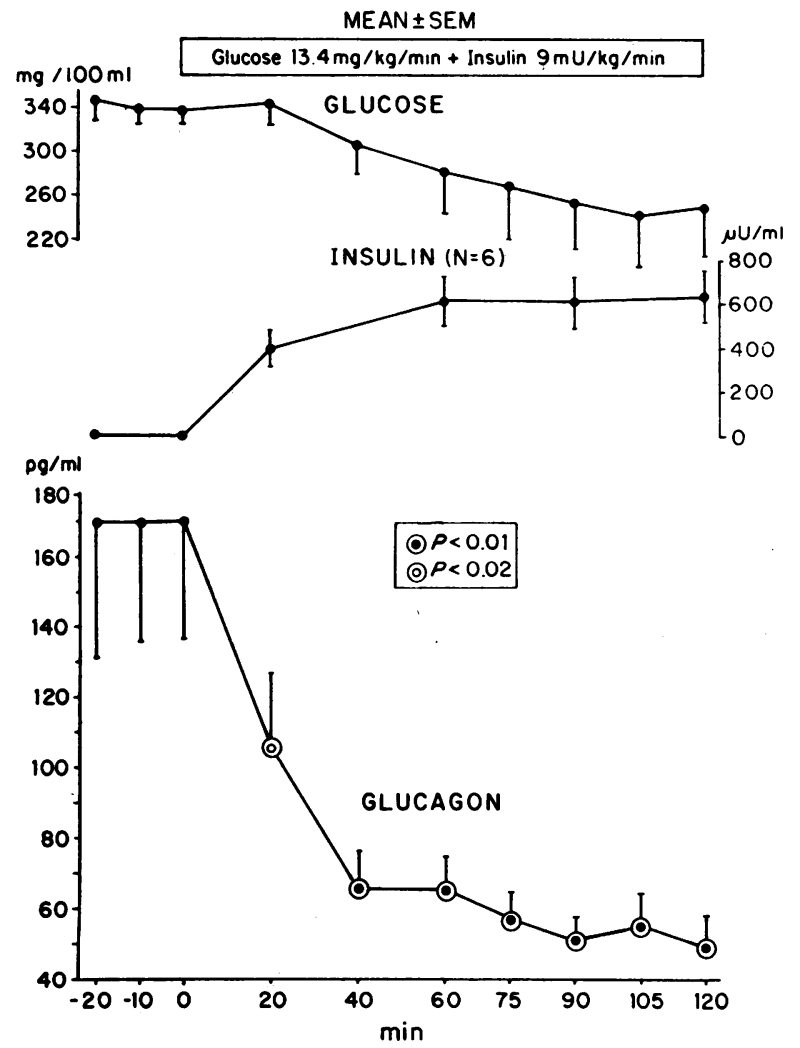

FIgURe 2 The effect of a large dose of insulin on plasma glucagon in seven dogs with alloxan diabetes of 7-12 mo duration.

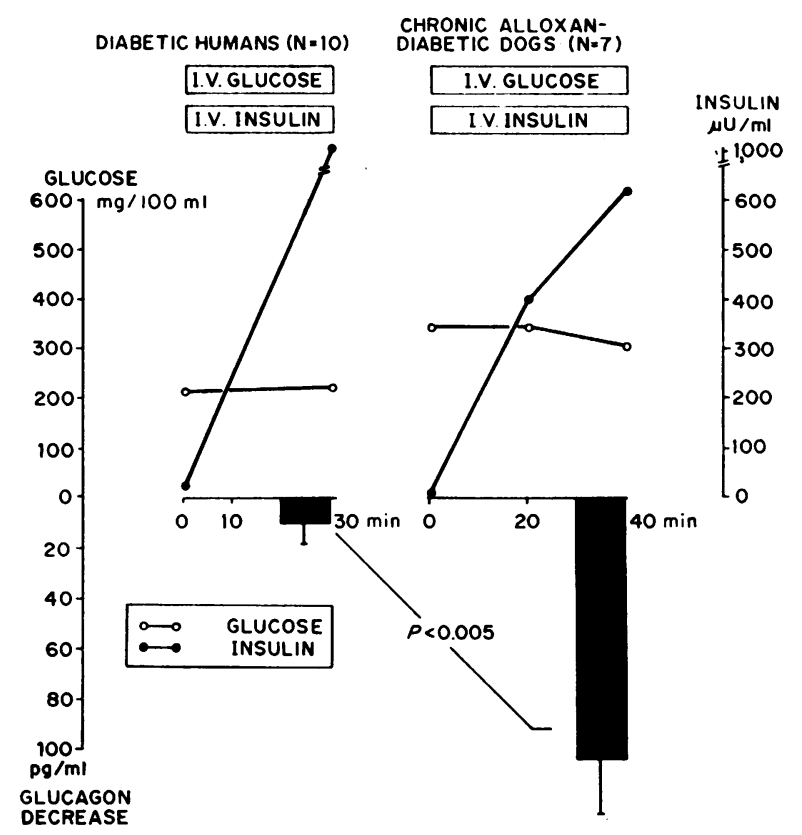

FIGURE 3 Comparison of plasma glucagon response to hyperglycemia in 10 diabetic humans (7) and in 7 dogs with long-standing alloxan diabetes during the administration of large quantities of insulin plus glucose. The solid bars represent the decrease in glucagon in the presence of marked hyperinsulinemia and hyperglycemia.

min and, at its peak, represented a mean increase of approximately $60 \mathrm{pg} / \mathrm{ml}$ above the mean base-line value. It is clear that in dogs with long-standing alloxan diabetes, a rising plasma glucose level not only failed to suppress glucagon secretion but seemed to provoke a paradoxical increase.

The effect of large amounts of insulin on alpha-cell responsiveness to hyperglycemia. To determine if marked hyperinsulinemia, comparable to the high levels that had failed to restore normal alpha-cell responsiveness to hyperglycemia in human diabetics, would do so in dogs with long-standing alloxan diabetes, glucagonfree insulin was infused at a rate of $9 \mathrm{mU} / \mathrm{kg} / \mathrm{min}$, together with glucose at a rate of $13.4 \mathrm{mg} / \mathrm{kg} / \mathrm{min}$, in a group of seven dogs with diabetes of from 7 to $12 \mathrm{mo}$ duration. The results are shown in Fig. $2.120 \mathrm{~min}$ after the start of the glucose-insulin infusion, at which point insulin had reached a mean level of $637 \mu \mathrm{U} / \mathrm{ml}(\mathrm{SEM} \pm$ 128), mean glucagon had declined significantly $(P<$ $0.01)$ below the base-line level of $171 \mathrm{pg} / \mathrm{ml}(\mathrm{SEM} \pm 34)$ to a nadir of $49 \mathrm{pg} / \mathrm{ml}(\mathrm{SEM} \pm 9)$. This sustained suppression of glucagon occurred in every animal and was statistically significant $(P<0.02)$ as early as $20 \mathrm{~min}$, the first time point examined.

In Fig. 3, these results are compared with the previously reported findings in human diabetics (7). In the humans, despite the sustained hyperinsulinemia, glu- 


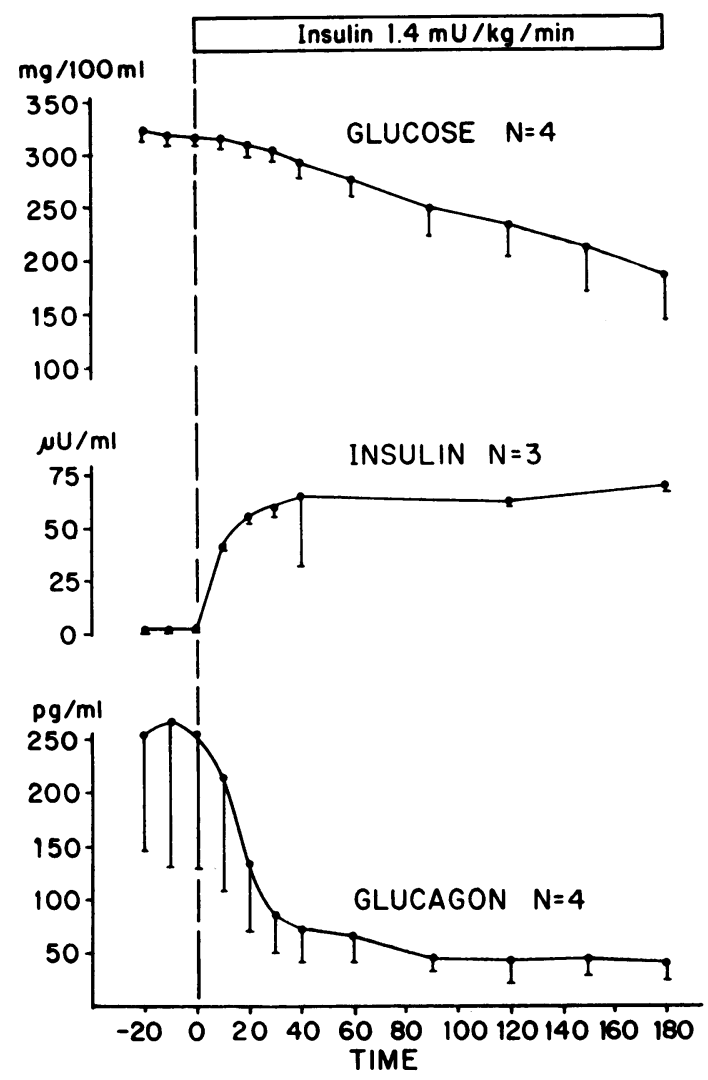

Figure 4 The effect of a low dose of intravenously infused insulin on plasma glucagon in four dogs with alloxan diabetes of 18 mo duration.

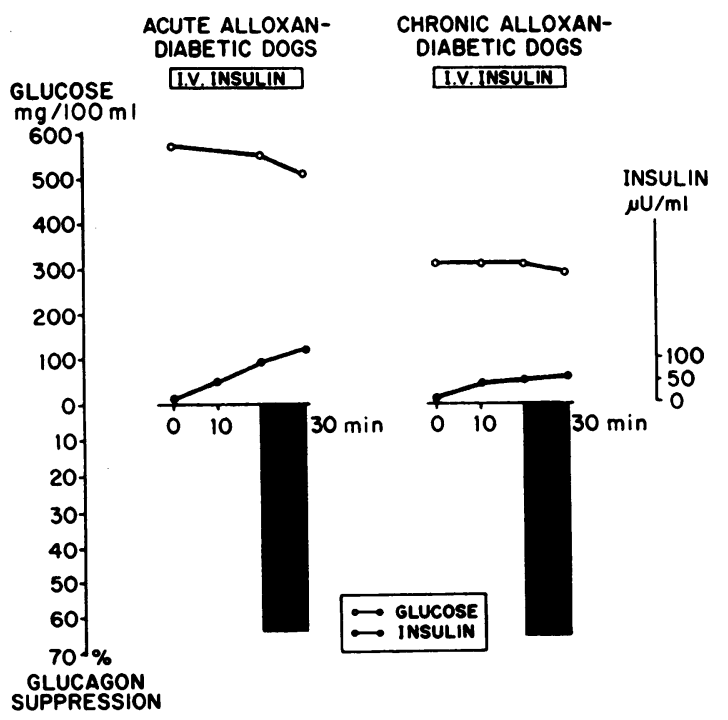

Figure 5 Comparison of the effectiveness of a low dose of insulin in restoring glucagon suppression by hyperglycemia in dogs with acute alloxan diabetes (6) and dogs with long-standing alloxan diabetes. The solid vertical bars represent the percent of glucagon suppression below the base line. cagon declined only $11 \mathrm{pg} / \mathrm{ml}$ or $11 \%$ of the base-line level in $30 \mathrm{~min}$, whereas in the dogs, glucagon declined $105 \mathrm{pg} / \mathrm{ml}$ or $61 \%$ in $40 \mathrm{~min}$.

It is clear from these results that long duration of acquired diabetes did not abolish the ability of insulin to correct alpha-cell responsiveness.

The effect of small amounts of insulin on alpha-cell unresponsiveness to hyperglycemia. Although the foregoing experiments reveal that in long-standing alloxan diabetes alpha-cell suppression by hyperglycemia can be fully restored by massive hyperinsulinemia, they do not indicate if small amounts of insulin also fully restore it, as in alloxan diabetes of short duration. To determine if long duration of acquired diabetes causes a loss in the response to small quantities of insulin, four dogs with alloxan diabetes of 18 mo duration were given an infusion of glucagon-free insulin at a rate of only $1.4 \mathrm{mU} /$ $\mathrm{kg} / \mathrm{min}$. The results are shown in Fig. 4 . Within $10 \mathrm{~min}$, at which point the mean insulin had risen only $43 \mu \mathrm{U} /$ $\mathrm{ml}$, glucagon had already declined in every dog. As insulin rose to a peak level of $71 \mu \mathrm{U} / \mathrm{ml}$, glucagon continued to fall to a mean nadir of $44 \mathrm{pg} / \mathrm{ml}$ at $90 \mathrm{~min}$. In Fig. 5 these results are compared with identical studies, previously reported in dogs with alloxan diabetes of $3 \mathrm{wk}$ duration or less (6). Clearly, long duration of alloxan diabetes did not impair the ability of small amounts of insulin to restore alpha-cell responsiveness to hyperglycemia.

\section{DISCUSSION}

The findings provide evidence that the effectiveness of insulin in restoring alpha-cell responsiveness to hyperglycemia is neither lost nor impaired in alloxan-diabetic dogs controlled on insulin for periods of up to $18 \mathrm{mo}$. They suggest that the relative ineffectiveness of insulin previously observed in human diabetes (7) may not be secondary to the long-standing beta-cell insufficiency, but rather a primary disorder. The fact that both alpha and beta cells originate from pancreatic ductular epithelium provides an ontogenic basis for the notion that if the diabetic beta cell is genetically defective, the diabetic alpha cell may also be defective. However, it is possible that factors in the human diabetics studied other than a genetic alpha abnormality accounted for the results.

Nevertheless, this information fits well with previous reports that alpha-cell unresponsiveness to hyperglycemia is present in well-controlled diabetics (4) with presumably normal or high levels of insulin and in mild diabetics (5), including those requiring only dietary treatment, whose levels of immunoreactive insulin levels are not reduced in an absolute sense.

Of incidental interest is the paradoxical rise of glucagon in chronically alloxan-diabetic dogs given intra- 
venous glucose. An adequate explanation for this observation is not as yet available. It is noteworthy, however, that a paradoxical increase in glucagon has also been observed in human diabetics after the ingestion of carbohydrate $(5,12)$ and may further complicate the problems of exogenous glucose disposal in the presence of an inadequate or absent rise in insulin.

\section{ACKNOWLEDGMENTS}

We wish to acknowledge the technical assistance of Miss Virginia Harris, Miss Kay McCorkle, Mrs. Shirley Harvey, Miss Sheela Rathod, Mrs. Margaret Bickham, and Mr. Daniel Sandlin.

This work was supported by National Institutes of Health grant AM 02700-15; The Upjohn Company, Kalamazoo, Mich.; Pfizer Laboratories Div., Pfizer Inc., New York; Bristol-Myers Co., New York; Mead Johnson Laboratories, Evansville, Ind.; Eli Lilly and Company, Indianapolis, Ind.; Richardson-Merrell Inc., Cincinnati, Ohio; Rabbit $30 \mathrm{~K}$ Fund, Ciba Pharmaceutical Company, Division of CIBA-GEIGY Corp., Summit, N. J.; Dr. Karl Thomae, GmbH, Germany; Hoffmann-La Roche Inc., Nutly, N. J.; and Hoechst Pharmaceuticals, Inc., Somerville, N. J.

\section{REFERENCES}

1. Unger, R. H., E. Aguilar-Parada, W. A. Müller, and A. M. Eisentraut. 1970. Studies of pancreatic alpha cell function in normal and diabetic subjects. J. Clin. Invest. $49: 837$.

2. Unger, R. H., A. M. Eisentraut, M. S. McCall, and L. L. Madison. 1962. Measurements of endogenous glucagon in plasma and the influence of blood glucose concentration upon its secretion. J. Clin. Invest. 41: 682.

3. Ohneda, A., E. Aguilar-Parada, A. M. Eisentraut, and R. H. Unger. 1969. Control of pancreatic glucagon secretion by glucose. Diabctes. 18: 1 .

4. Aguilar-Parada, E., A. M. Eisentraut, and R. H. Unger. 1969. Pancreatic glucagon secretion in normal and diabetic subjects. Am. J. Mcd. Sci. 257: 415.

5. Müller, W. A., G. R. Faloona, E. Aguilar-Parada, and R. H. Unger. 1970. Abnormal alpha-cell function in diabetes: Response to carbohydrate and protein ingestion. N. Engl. J. Med. 283: 109.

6. Müller, W. A., G. R. Faloona, and R. H. Unger. 1971. The effect of experimental insulin deficiency on glucagon secretion. J. Clin. Invest. 50: 1992.

7. Unger, R. H., L. L. Madison, and W. A. Müller. 1972. Abnormal alpha cell function in diabetics: response to insulin. Diabetes. $21: 301$.

8. Braaten, J. T., G. R. Faloona, and R. H. Unger. 1973. Comparison of alpha cell dysfunction in acquired and inherited diabetes mellitus. Diabetes. 22 (Suppl. 1): 302.

9. Yalow, R. S., and S. A. Berson. 1960. Immunoassay of endogenous plasma insulin in man. J. Clin. Invest. 39: 1157.

10. Herbert, V., K. S. Lau, C. W. Gottlieb, and B. J. Bleicher. 1965. Coated charcoal immunoassay of insulin. J. Clin. Endocrinol. Metab. 25: 1375.

11. Faloona, G. R. 1973. Radioimmunoassay: glucagon and GLI. In Methods in Investigative and Diagnostic Endocrinology, Non-Pituitary Hormones. S. A. Berson and R. Yalow, editors. North-Holland Publishing Co., Amsterdam. 919.

12. Buchanan, K. D., and A. M. McCarroll. 1972. Abnormalities of glucagon metabolism in untreated diabetes mellitus. Lancet. 2 : 1394. 